\title{
Economic Analysis of Cellulase Production METHODS FOR BIO-ETHANOL
}

\author{
J. Zhuang, M. A. Marchant, S. E. Nokes，H. J. Strobel
}

\begin{abstract}
The cost of cellulase enzymes has limited the feasibility of producing ethanol from fibrous biomass. Traditional submerged fermentation (SmF) was compared to an alternative method of producing cellulase, solid state cultivation (SSC). Results from an economic analysis indicated that the unit costs for cellulase enzyme production were $\$ 15.67$ (The prices are all 2004 prices in this article, except otherwise stated. We deflated newer prices to 2004 prices using a deflation factor 0.9 per year and inflated older prices to 2004 prices using an inflation factor 1.1.) per kilogram (\$/kg) and $\$ 40.36 / \mathrm{kg}$, for the SSC and SmF methods, respectively, while the corresponding market price was over $\$ 90.00 / \mathrm{kg}$. A sensitivity analysis conducted using Monte Carlo simulation also suggests that the unit cost of production using the SSC method is lower than the unit cost of production using $\mathrm{SmF}$ with a certainty of 99.6\% (9,959 out of 10,000 cases). These results indicate that the SSC method may be a more economical method of cellulase production, thereby reducing bio-ethanol production costs. SSC may increase the potential that bio-ethanol will become a viable supplemental fuel source in light of current economic, political, and environmental issues.
\end{abstract}

Keywords. Biomass, Clostridium thermocellum, Enzyme production, Ethanol, Solid state fermentation, Submerged fermentation.

$\mathrm{T}$ he United States accounted for more than $25 \%$ of total global oil consumption in 2004 but produces only $10 \%$ of the global supply and has only $2 \%$ of global reserves (Brown, 2003). The huge gap between U.S. oil consumption and production is filled by foreign oil imports, especially from the Middle East, which makes the United States vulnerable to potential oil supply disruptions (such as Hurricane Katrina in 2005). Not surprisingly, the U.S. Department of Energy, Office of Energy Efficiency and Renewable Energy (US-DOE-EERE) has recommended that the nation "dramatically reduce or even end dependence on foreign oil" (US-DOE-EERE, 2007). Besides the economic burdens, automobile emissions related to petroleum-based fossil fuels (e.g., gasoline and diesel) are sources of global warming and reduced air quality (Brown, 2003).

Submitted for review in August 2006 as manuscript number BE 6647; approved for publication by the Biological Engineering Division of ASABE in April 2007.

The authors acknowledge the financial support of the U.S. Department of Agriculture (NRI Competitive Grants Program \#2001-35504-10106). The investigation reported in this paper (No. 07-05-029) is part of a project of the Kentucky Agricultural Experiment Station and is published with approval of the director.

The authors are Jun Zhuang, Research Assistant, Department of Industrial and Systems Engineering, University of Wisconsin-Madison, Madison, Wisconsin; Mary A. Marchant, Associate Dean and Director of Academic Programs, College of Agriculture and Life Sciences, Virginia Tech, Blacksburg, Virginia; Sue E. Nokes, ASABE Member Engineer, Professor, Department of Biosystems and Agricultural Engineering, University of Kentucky, Lexington, Kentucky; and Herbert J. Strobel, Associate Professor, Department of Animal and Food Science, University of Kentucky, Lexington, Kentucky. Corresponding author: Jun Zhuang, 3237 Mechanical Engineering Building, 1513 University Avenue, Madison, WI 53706-1572; phone: 608-263-2687; fax: 608-265-9094; e-mail: jzhuang@wisc.edu.
The continued development of the bio-ethanol industry provides one partial solution to the problems associated with petroleum. Converting agricultural or forest biomass into ethanol is appealing because (1) the raw materials are inexpensive and available in large quantities; (2) such technology is inherently a value-added process; and (3) automobile emissions may be reduced with ethanol as a fuel source, which may also reduce global warming and air pollution (Brown, 2003). In this article, we are distinguishing bio-ethanol from ethanol, whereby bio-ethanol is produced from starch-based fermentation processes.

Based on these advantages, large-scale bio-ethanol production using cellulose (the main component of inexpensive agricultural or forest biomass) may result in economic and environmental benefits. However, a number of factors currently limit the commercial production of ethanol from cellulose. For example, cellulase enzyme production cost estimates range as high as $25 \%$ to $50 \%$ of total ethanol production costs (Himmel et al., 1997; Ruth, 2003), based on production costs from traditional submerged fermentation $(\mathrm{SmF})$ technology. An alternative approach for producing cellulase enzymes is solid state cultivation (SSC). This technology is considerably different than submerged fermentation (SmF) (Holker and Lenz, 2005; Krishna, 2005), and because of these inherent differences, solid state cultivation (SSC) has the potential to reduce enzyme production costs. Therefore, we performed an economic analysis comparing cellulase production using $\mathrm{SmF}$ versus SSC.

\section{RESEARCH OBJECTIVE}

The objective of this research was to test the hypothesis that unit costs for cellulase production using SSC are lower than the unit costs obtained using the traditional SmF 
production method. Economic and sensitivity analyses were conducted to achieve this objective.

\section{Background on Cellulase Production}

A key step in producing ethanol from biomass is the conversion of complex plant carbohydrates to simple sugars (through a process called saccharification) that can be fermented by microorganisms. When fibrous biomass is employed, the saccharification process is largely carried out by cellulase enzymes (fig. 1).

\section{HisTORY}

Traditionally, enzymes used in commercial application are produced using the submerged fermentation $(\mathrm{SmF})$ method in which the microorganisms are cultivated in a nutrient-rich aqueous medium. However, considerable expense can be involved in concentrating and extracting enzymes from this largely aqueous environment. An alternative to the traditional $\mathrm{SmF}$ method is solid state cultivation (SSC), which involves growth of microorganisms on solid materials in the absence of free liquid (Cannel and Young, 1980). Since SSC involves relatively little liquid when compared with SmF, downstream processing from SSC is theoretically simpler and less expensive (fig. 2). While SSC is not widely used, it is not a new idea. Foods fermented

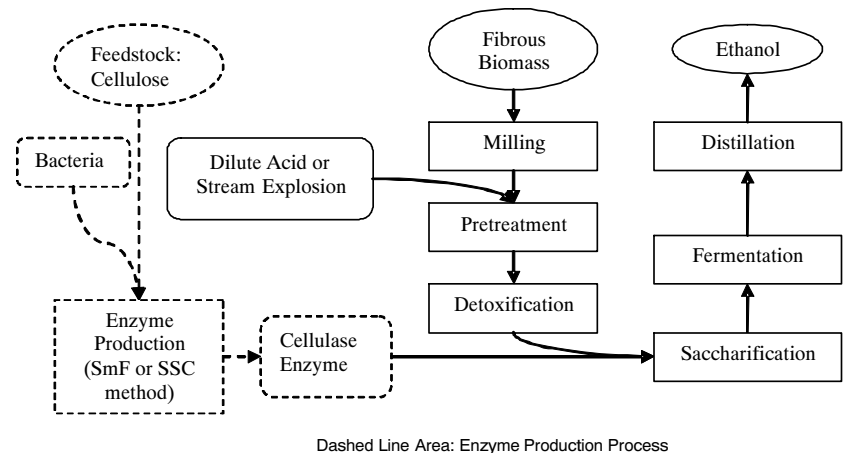

Figure 1. Enzyme production component within the ethanol production process (Source: Simplified flowchart from Aden et al., 2002). from moist solids, such as soy sauce and miso soup, have been prepared using SSC in Asian countries for thousands of years. However, SSC was ignored in western countries due to the adoption of the SmF method (Pandey, 2003). Since the 1990s, a renewed interest in SSC has developed, partially due to the recognition that many microorganisms may produce products more effectively under SSC (Pandey et al., 1999).

\section{A Comparison between the SmF and SSC Methods}

From an economic viewpoint, the SSC method has at least three advantages over the traditional $\mathrm{SmF}$ method for enzyme production: (1) lower consumption of water and energy; (2) reduced waste stream; and (3) more highly concentrated product. The SSC method is reputed to require less unitary capital and operating costs than the traditional SmF method (Kumar and Lonsane, 1987; Durand et al., 1997). Although there are potential advantages of the SSC method, there are also technical problems limiting its large-scale implementation. For instance, heat and mass transfer is more difficult in SSC than in SmF because of limited diffusion through the solid substrate (Deschamps and Huet, 1984; Mitchell, et al., 2003). If left uncontrolled, heat accumulation and decline in available oxygen could result in the cessation of mesophilic aerobic microbial activity and the consequential cessation of enzyme production.

One approach to overcome the heat and mass transfer issue is to use organisms that tolerate elevated temperatures and anaerobic conditions. Previous work has indicated that a variety of anaerobic thermophilic bacteria can be grown using SSC (Chinn et al., 2006). In particular, Clostridium thermocellum appeared promising since this organism produces a considerable amount of cellulase (Demain et al., 2005).

\section{Enzyme Production Process AND COMPUTER Simulation}

Process simulation software was used to estimate data for the large scale economic analysis. Enzyme production processes using the SmF and SSC methods were simulated

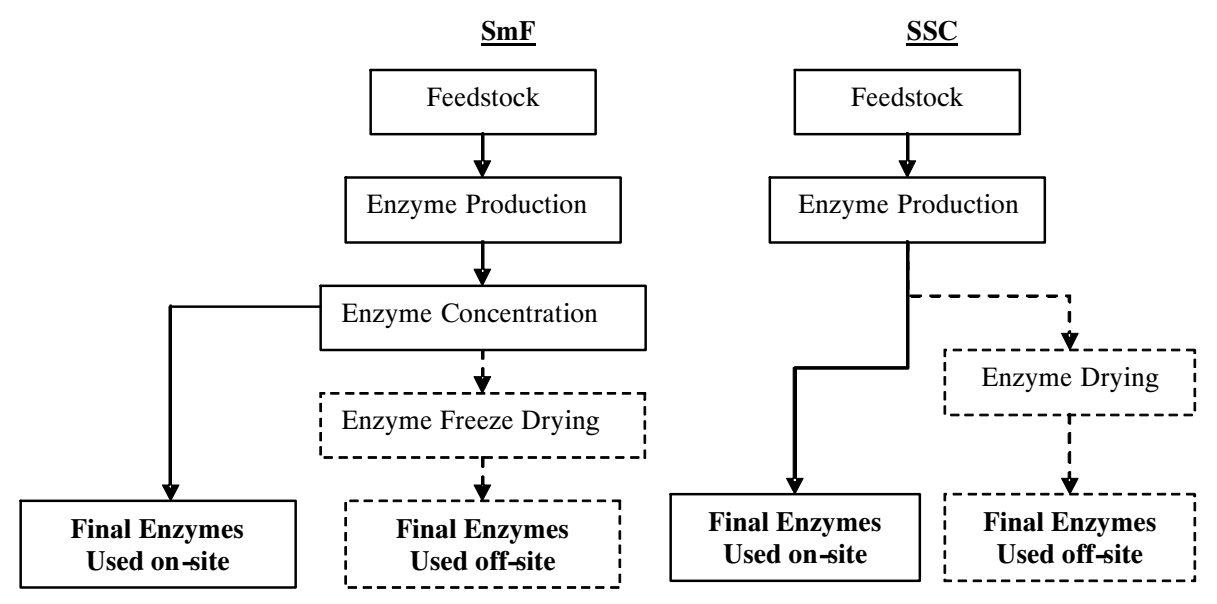

Straight (dashed) lines represent onsite (off-site) enzyme production process

Figure 2. Flowcharts of enzyme production using the traditional submerged fermentation (SmF) method compared to the solid state cultivation (SSC) method. 

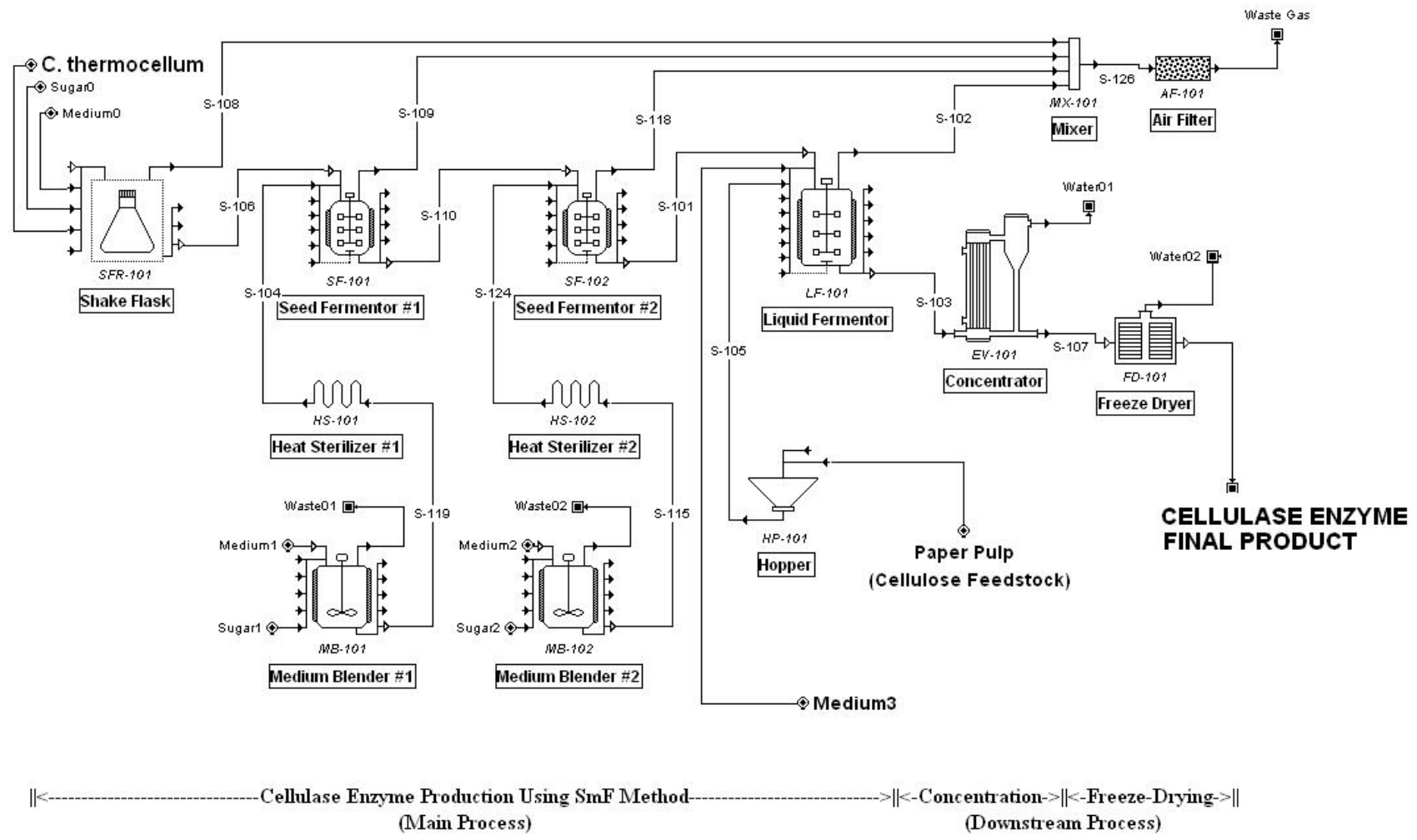

Figure 3. The traditional submerged fermentation (SmF) method for producing enzymes-process specification.
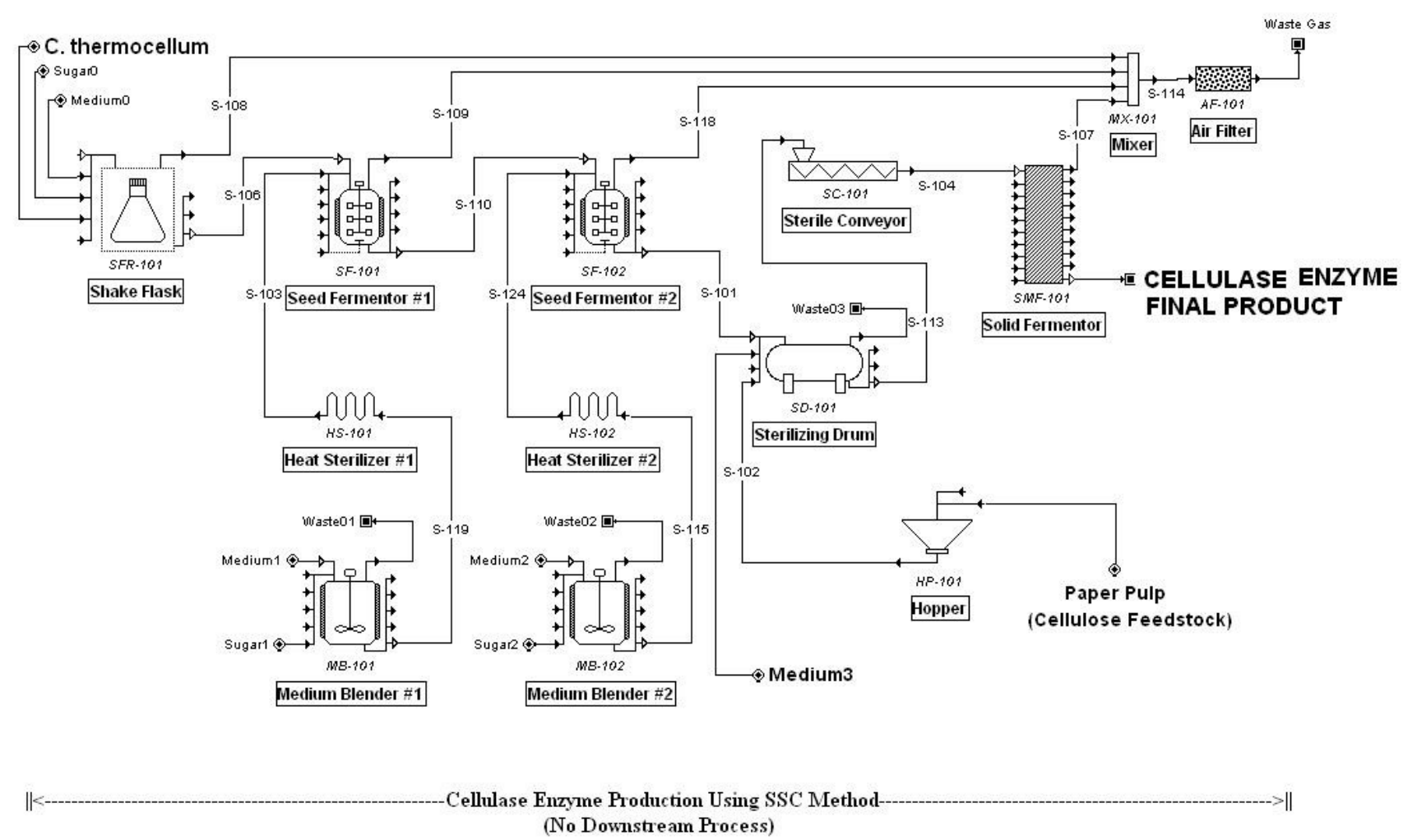

Figure 4. The solid state cultivation (SSC) method for producing enzymes-process specification.

in the SuperPro Designer 5.5 software (Intelligen, Inc, 2006), which is commonly used in pharmaceutical and biotechnology industries. Figures 3 and 4 present the process flowsheets for cellulase production using the SSC and SmF methods, respectively (see Appendix for explanations of the flowsheets). 


\section{DATA}

For convenience, input data were separated into six groups: (1) properties of components and mixtures and their corresponding economic data; (2) feed stream data; (3) mass transfer data; (4) equipment cost data; (5) data for economic parameters, such as project life and discount rates; and (6) data for other technical parameters, including set-up time, processing time, temperatures, flow rates, among others. The first and second groups of data are available from the authors. The fifth and sixth groups of data were specified within the simulation software. The remainder of this section will focus on the third and fourth groups of data: mass transfer and equipment cost data.

\section{Mass Transfer Data}

For the purpose of this economic analysis, fermentation was divided into three components: input (cellulose feedstock), growth environment (media), and output [new bacteria, cellulase enzyme final product, and other fermentation end products (FEP)], as shown in the following mass balance equation:

$$
\begin{aligned}
& \text { Cellulose Feedstock } \rightarrow \text { New Bacteria }+ \\
& (500,000 \mathrm{~kg}) \quad(50,000 \mathrm{~kg})
\end{aligned}
$$

$$
\begin{gathered}
\text { Cellulase Enzyme Final Product + FEP } \\
(10,000 \mathrm{~kg})
\end{gathered}
$$

We assumed that the main fermentors (the liquid fermentor for SmF in fig. 3 and solid fermentor for SSC in fig. 4, respectively), when operated at production scale, would produce $10,000 \mathrm{~kg}$ of cellulase final product per batch. Zhang and Lynd (2003) quantified the cellulase produced by C. thermocellum and found cellulase predictably represented $20 \%$ of the $C$. thermocellum bacterial mass, $10,000 \mathrm{~kg}$ of cellulase would be produced from $50,000 \mathrm{~kg}$ of new bacterial mass as shown in the right hand side of equation 1 . Based on previous laboratory studies (Lynd et al., 1989), we assumed that the cellulose-bacteria conversion ratio was 10:1 (the impact of this assumption is investigated in the Monte Carlo analysis below), such that in order to grow $50,000 \mathrm{~kg}$ of new bacteria, $500,000 \mathrm{~kg}$ of cellulose must be consumed (table 1). We assume that reaction efficiency to be $100 \%$. Furthermore, in order to obtain $500,000 \mathrm{~kg}$ of cellulose, $916,422 \mathrm{~kg}$ of paper pulp is required as a feedstock for the main fermentor, because the typical mass ratio of cellulose to paper pulp is 0.5456 (Lynd et al., 2001). The wet basis moisture content used for SSC was 70\% (Chinn et al., 2006); therefore the media required for $916,422 \mathrm{~kg}$ of paper pulp was calculated to be $2,134,118 \mathrm{~kg}$.

Input data for the $\mathrm{SmF}$ method were obtained from Wooley et al. (1999), where the initial cellulose feedstock concentration was $4 \%$; therefore the media required for the $\mathrm{SmF}$ method was $12,500,000 \mathrm{~kg}$. As is typical of seed fermentors, it was assumed that innoculum volume increased 100 -fold in each of the following vessels: shake flasks, seed fermentors and main fermentors sequentially, for both the SmF and SSC methods (Shuler and Kargi, 2002). The data for the cellulose feedstock, media, bacteria and cellulase enzymes discussed in equation 1 were scaled down from the main fermentor to seed fermentor \#2, then to seed fermentor $\# 1$, and then to the shake flask, by a factor 0.01 , respectively (table 1).

\section{EQUIPMENT COST}

SuperPro Designer 5.5 software scales up equipment purchase costs (EPC) by using a power relationship for equipment capacities, as shown in equation 2 , where $C_{0}$ is the base item cost, $Q$ and $Q_{o}$ are the new and base equipment capacities, respectively, and a is set as 0.6 using the software default (also see Peters et al., 2003).

$$
E P C=C_{0}\left(\frac{Q}{Q_{0}}\right)^{a}
$$

Equipment cost estimations, equipment sizes and base equipment sources are listed in tables 2 and 3 for enzyme production using the SmF and SSC methods, respectively.

\section{Economic And Sensitivity AnAlyses Unit Cost ANALYsis}

In order to calculate unit costs for the enzyme production simulation, direct fixed capital ( $D F C$, table 4$)$ and operating costs were calculated (eq. 3 ).

$$
\mathrm{DFC}=\mathrm{DC}+\mathrm{IC}+\mathrm{OC}
$$

where DC stands for direct costs, IC for indirect costs, and OC for other costs. Direct costs (DC) included purchase costs, installation costs, piping, instrumentation, insulation,

\begin{tabular}{|c|c|c|c|c|c|c|}
\hline & & $\begin{array}{l}\text { Shake } \\
\text { Flask }\end{array}$ & $\begin{array}{c}\text { Seed } \\
\text { Fermentor \#1 }\end{array}$ & $\begin{array}{c}\text { Seed } \\
\text { Fermentor \#2 }\end{array}$ & $\begin{array}{l}(\mathrm{SmF}) \text { Liquid } \\
\text { Fermentor }\end{array}$ & $\begin{array}{l}\text { (SSC) Solid } \\
\text { Fermentor }\end{array}$ \\
\hline \multirow[t]{4}{*}{ Input } & C. thermocellum & 0.0005 & 0.05 & 5 & 500 & 500 \\
\hline & Cellulose & 0.5000 & 50.00 & $5,000.0$ & $500,000[\mathrm{a}]$ & $500,000^{[a]}$ \\
\hline & Paper pulp & N/A & N/A & N/A & 916,422 & 916,422 \\
\hline & Media & 12.5000 & $1,250.00$ & $125,000.0$ & $12,500,000$ & $2,134,118$ \\
\hline \multirow[t]{3}{*}{ Output } & Cellulase enzyme final product & 0.0100 & 1.00 & 100.0 & $10,000^{[\mathrm{d}]}$ & $10,000^{[\mathrm{d}]}$ \\
\hline & C. thermocellum $[\mathrm{c}]$ & 0.0500 & 5.00 & 500.0 & 50,000 & 50,000 \\
\hline & $\mathrm{FEP}[\mathrm{b}]$ & 0.4400 & 44.00 & $4,400.0$ & 440,000 & 440,000 \\
\hline
\end{tabular}
electrical facilities, buildings costs, yard improvements and auxiliary facilities. Purchase costs were the sum of all equipment costs. Installation costs were the sum of costs related to installation of all equipment. As is typical for

Table 1. Mass balance in the vessels in the SmF and SSC methods (kg).

[a] Contained in the paper pulp, not from cellulose powder.

[b] FEP = fermentation end product;

[c] Output of $C$. thermocellum from previous vessel (e.g., shake flask) is the input of the $C$. thermocellum for the next vessel (e.g., seed fermentor \#1);

[d] All the data were based on a starting-point production rate: 10,000 $\mathrm{kg}$ of cellulase enzyme per batch from main fermentor; 
Table 2. Specification and costs of the major equipment required for the SmF method (year $2004 \$$ [a]).

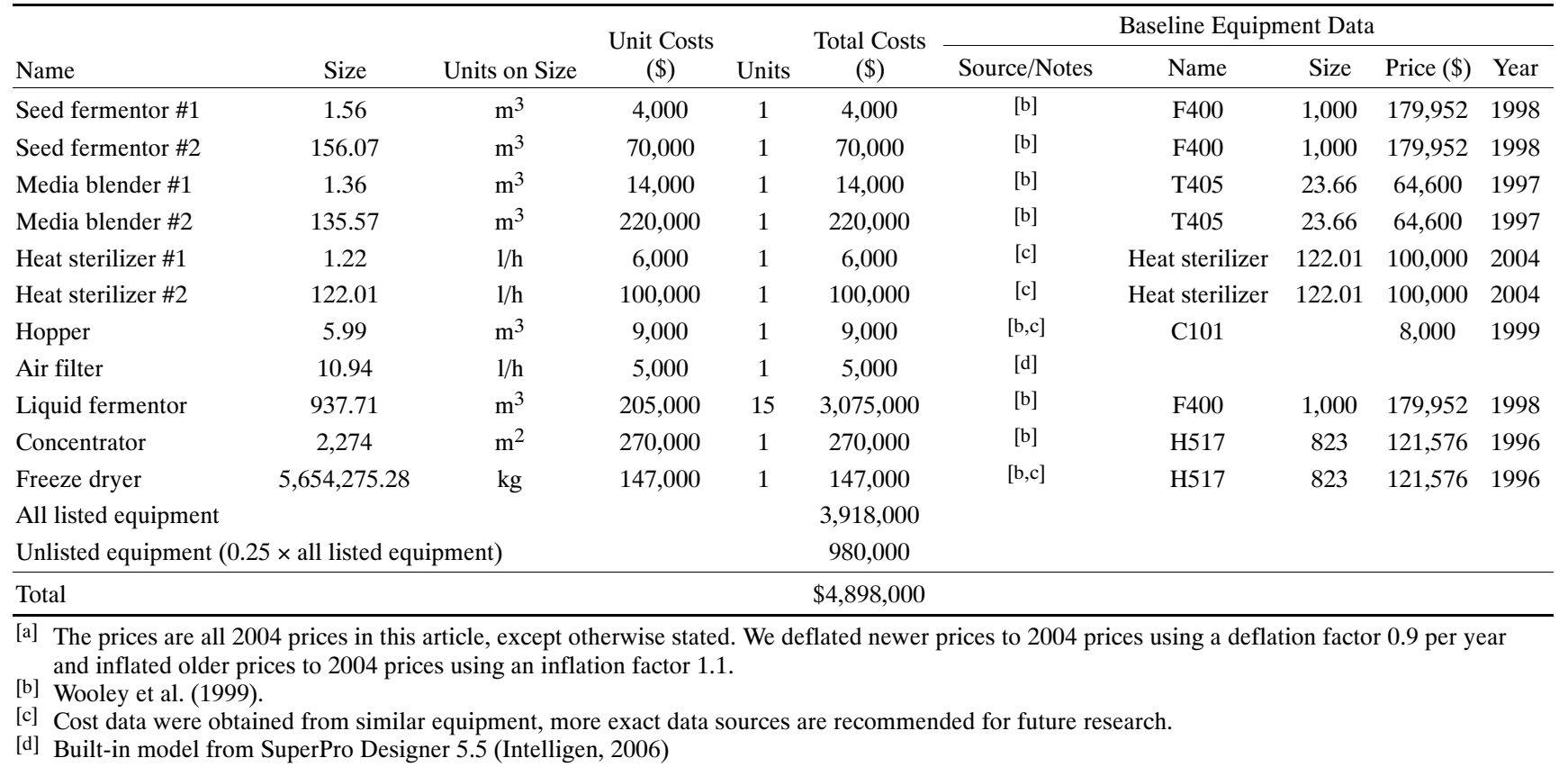

costing a processing plant, the factor method within the software (also see Peters et al., 2003) was used to estimate these costs. Indirect costs (IC) included engineering costs (estimated to be $0.25^{*} D C$ ) plus construction costs (estimated to be $0.35^{*} D C$ ). Other costs (OC) consisted of contractors' fees $\left(0.05^{*}(D C+I C)\right)$ and contingency costs $(0.10 *(D C+I C))$.

Operating costs were the sum of (1) raw materials (table 5), (2) utilities (table 6), (3) labor, (4) facilities, and (5) laboratory $/ \mathrm{QC} / \mathrm{QA}(\mathrm{QC}=$ quality control; $\mathrm{QA}=$ quality analysis). Total labor costs were estimated to be $\$ 2,773,000$ and $\$ 2,116,000$ per year for the SmF and SSC methods, respectively. Facility costs accounted for depreciation of direct fixed capital $(D F C)$ costs, equipment maintenance, insurance, local taxes, and other overhead-type factory expenses. The laboratory/QC/QA costs accounted for offline analyses and quality control costs, estimated at $15 \%$ of total labor costs. Total annual operating costs (table 7) were estimated to be $\$ 8,230,000$ for the SSC method and $\$ 30,576,000$ for the SmF method.

The unit cost for the cellulase enzyme final product was calculated as the quotient of the annual operating costs divided by the annual enzyme production rate [output per batch (OPB) times the number of batches per year (NBPY)]. Based on the output from the four fermentation vessels (table 1), the total enzyme output per batch was $10,101 \mathrm{~kg}$ of cellulase. The number of batches per year (NBPY) was calculated as 75 and 52 for the SmF and SSC methods,

Table 3. Specification and costs of the major equipment required for the SSC method (year 2004 \$).

\begin{tabular}{|c|c|c|c|c|c|c|c|c|c|c|}
\hline \multirow[b]{2}{*}{ Name } & \multirow[b]{2}{*}{ Size } & \multirow[b]{2}{*}{ Units on Size } & \multirow{2}{*}{$\begin{array}{c}\text { Unit Costs } \\
(\$)\end{array}$} & \multirow[b]{2}{*}{ Units } & \multirow{2}{*}{$\begin{array}{c}\text { Total Costs } \\
\text { (\$) }\end{array}$} & \multicolumn{5}{|c|}{ Baseline Equipment Data } \\
\hline & & & & & & Source & Name & Size & Price $(\$)$ & Year \\
\hline Seed fermentor \#1 & 1.56 & $\mathrm{~m}^{3}$ & 4,000 & 1 & 4,000 & {$[\mathrm{~b}]$} & F400 & 1,000 & 179,952 & 1998 \\
\hline Seed fermentor \#2 & 156.07 & $\mathrm{~m}^{3}$ & 70,000 & 1 & 70,000 & {$[\mathrm{~b}]$} & F400 & 1,000 & 179,952 & 1998 \\
\hline Media blender \#1 & 1.36 & $\mathrm{~m}^{3}$ & 14,000 & 1 & 14,000 & [b] & $\mathrm{T} 405$ & 23.66 & 64,600 & 1997 \\
\hline Media blender \#2 & 135.57 & $\mathrm{~m}^{3}$ & 220,000 & 1 & 220,000 & {$[\mathrm{~b}]$} & T405 & 23.66 & 64,600 & 1997 \\
\hline Heat sterilizer \#2 & 1.22 & $\mathrm{~L} / \mathrm{h}$ & 6,000 & 1 & 6,000 & {$[\mathrm{e}]$} & Heat sterilizer & 122.01 & 100,000 & 2004 \\
\hline Heat sterilizer \#2 & 122.01 & $\mathrm{~L} / \mathrm{h}$ & 100,000 & 1 & 100,000 & {$[\mathrm{e}]$} & Heat sterilizer & 122.01 & 100,000 & 2004 \\
\hline Hopper & 5.99 & $\mathrm{~m}^{3}$ & 9,000 & 1 & 9,000 & {$[\mathrm{~b}, \mathrm{e}]$} & C101 & & 8,000 & 1999 \\
\hline Air filter & 10.94 & $\mathrm{~L} / \mathrm{h}$ & 5,000 & 1 & 5,000 & [e] & & & & \\
\hline Solid fermentor & 2,741 & $\mathrm{~m}^{3}$ & $2,194,000$ & 1 & $2,194,000$ & {$[\mathrm{a}]$} & SSF fermentor & 35.41 & 138,800 & 2000 \\
\hline Sterilizing drum & 2,741 & $\mathrm{~m}^{3}$ & 157,000 & 1 & 157,000 & {$[\mathrm{~b}]$} & T505 & 50 & 11,900 & 1999 \\
\hline Sterile conveyor & 15.00 & $\mathrm{~m}$ & 71,000 & 1 & 71,000 & {$[c, e]$} & C104 & & 60,000 & 2000 \\
\hline \multicolumn{3}{|l|}{ All listed equipment } & & & $2,850,000$ & & & & & \\
\hline \multicolumn{3}{|c|}{ Unlisted equipment $(0.25 \times$ all listed equipment $)$} & & & 712,000 & & & & & \\
\hline Total & & & & & $\$ 3,562,000$ & & & & & \\
\hline
\end{tabular}

[a] Castilho et al. (2000).

[b] Wooley et al. (1999).

[c] Aden et al. (2002).

[d] Built-in model from SuperPro Designer 5.5.

[e] Cost data was obtained from similar equipment, better data sources are recommended for future research. 
Table 4. Direct fixed capital costs estimates for enzyme production using the SmF and SSC methods (year 2004 \$).

\begin{tabular}{|c|c|c|}
\hline Item & $\mathrm{SmF}$ & SSC \\
\hline \multicolumn{3}{|l|}{ Direct Costs (DC): } \\
\hline Equipment purchase costs $[\mathrm{a}]$ & $\$ 4,898,000$ & $\$ 3,562,000$ \\
\hline Installation & $1,453,000$ & $1,708,000$ \\
\hline Process piping & $1,714,000$ & $1,247,000$ \\
\hline Instrumentation & $1,959,000$ & $1,425,000$ \\
\hline Insulation & 147,000 & 107,000 \\
\hline Electrical & 490,000 & 356,000 \\
\hline Buildings & $2,204,000$ & $1,603,000$ \\
\hline Yard improvement & 735,000 & 534,000 \\
\hline Auxiliary facilities & $1,959,000$ & $1,425,000$ \\
\hline Total Direct Costs (DC) & $15,558,000$ & $11,968,000$ \\
\hline \multicolumn{3}{|l|}{ Indirect Costs (IC): } \\
\hline Engineering & $\$ 3,890,000$ & $\$ 2,992,000$ \\
\hline Construction & $5,445,000$ & $4,189,000$ \\
\hline Total Indirect Costs (IC) & $9,335,000$ & $7,181,000$ \\
\hline \multicolumn{3}{|l|}{ Other Costs (OC): } \\
\hline Contractor's fee & $\$ 1,245,000$ & $\$ 957,000$ \\
\hline Contingency & $2,489,000$ & $1,915,000$ \\
\hline Total Other Costs (OC) & $3,734,000$ & $2,872,000$ \\
\hline $\begin{array}{l}\text { Total estimated Direct } \\
\text { Fixed Capital (DFC) costs }\end{array}$ & $\$ 28,627,000$ & $\$ 22,021,000$ \\
\hline
\end{tabular}

[a] Data from tables 2 and 3.

respectively, because SmF can be turned around faster than SSC. Therefore the annual production rate was $757,576 \mathrm{~kg}$ of cellulase for the $\mathrm{SmF}$ method and 525,252 $\mathrm{kg}$ of cellulase for the SSC method. The unit cost for cellulase enzyme production using the $\mathrm{SmF}$ method was $\$ 40.36 / \mathrm{kg}$. In comparison the unit cost for cellulase enzyme production using the SSC method equaled $\$ 15.67$ per kilogram. Note also the current cellulase enzyme selling price is over $\$ 100 / \mathrm{kg}$ (Filer, 2006), which is deflated to be $\$ 90 / \mathrm{kg}$ for 2004 prices using a deflation factor of 0.9 , in order to make comparisons.

This unit cost was divided into the relative contribution of each cost source (table 8). Input costs for laboratory/quality control/quality analysis, facility, and labor components of the SSC method are either nearly the same or slightly greater than the SmF method. However, utilities and raw material costs used by the SSC method are estimated to be much lower than the $\mathrm{SmF}$ method. Since these components contributed a heavy cost share weight, the SSC method is predicted to be more economical than the SmF method.

\section{Sensitivity Analysis for Production Scale}

This section assesses the influence of a change of production scale (from $-80 \%$ to $+80 \%$ ) on the unit costs to produce cellulase enzymes for the SmF and SSC methods. Table 9 shows the results of this sensitivity analysis: the production scale had significant impact on the unit costs for the $C$. thermocellum enzyme production, ranging from $\$ 37.77 / \mathrm{kg}$ to $\$ 58.90 / \mathrm{kg}$ for the $\mathrm{SmF}$ method and from $\$ 11.27 / \mathrm{kg}$ to $\$ 42.51 / \mathrm{kg}$ for the SSC methods, respectively. Consistent with the above results where the unit costs for enzyme production were $\$ 40.36 / \mathrm{kg}$ for $\mathrm{SmF}$ and $\$ 15.67 / \mathrm{kg}$ for SSC, the SSC method had lower unit costs than the SmF method regardless of production scale changes. These results indicate that the SSC method was economical at all scales, if similar sized facilities were compared.

\section{Monte Carlo Analysis}

Since the input variables (raw material prices, facility costs, and cellulose-enzyme conversion ratio) have simultaneous uncertainty, reporting a single economic prediction is an oversimplification. Monte Carlo analysis, a probabilistic method, provides greater insight into the unit

Table 5. Raw material costs for enzyme production using the SmF and SSC methods (year 2004 \$).

\begin{tabular}{|c|c|c|c|c|c|c|c|}
\hline \multirow[b]{2}{*}{ Raw Material } & \multirow[b]{2}{*}{ Unit Cost } & \multicolumn{3}{|c|}{$\mathrm{SmF}$} & \multicolumn{3}{|c|}{ SSC } \\
\hline & & $\mathrm{SmF}(\mathrm{kg})$ & Annual Cost (\$) & $(\%)$ & Annual Amount (kg) & Annual Cost (\$) & $(\%)$ \\
\hline Paper pulp & 0 & $68,731,738$ & 0 & 0 & $47,653,959$ & 0 & 0 \\
\hline Cellulose & 0 & 378,751 & 0 & 0 & 262,626 & 0 & 0 \\
\hline Media & 0.003852 & $946,973,003$ & $3,648,000$ & 97.2 & $117,758,290$ & 454,000 & 99.03 \\
\hline C. thermocellum & 0 & 0 & 0 & 0 & 0 & 0 & 0 \\
\hline Nitrogen & 0.005 & 365,226 & 2,000 & 0.05 & 3,093 & 0 & 0 \\
\hline Water & 0.000233 & $442,807,794$ & 103,000 & 2.75 & $19,006,179$ & 4,000 & 0.97 \\
\hline Total & & & $\$ 3,753,000$ & $100 \%$ & & $\$ 458,000$ & $100 \%$ \\
\hline
\end{tabular}

Table 6. Utility costs for enzyme production using the SmF and SSC methods (year 2004 \$).

\begin{tabular}{|c|c|c|c|c|c|c|c|}
\hline \multirow[b]{2}{*}{ Utility ${ }^{[a]}$} & \multirow[b]{2}{*}{$\begin{array}{l}\text { Unit Cost } \\
\text { (\$/unit) })^{[b]}\end{array}$} & \multicolumn{3}{|c|}{$\mathrm{SmF}$} & \multicolumn{3}{|c|}{$\mathrm{SSC}$} \\
\hline & & $\begin{array}{l}\text { Annual Amount } \\
\text { (unit) }\end{array}$ & $\begin{array}{c}\text { Annual Cost } \\
\text { (\$) }\end{array}$ & $(\%)$ & $\begin{array}{l}\text { Annual Amount } \\
\text { (unit) }\end{array}$ & $\begin{array}{c}\text { Annual Cost } \\
(\$)\end{array}$ & $(\%)$ \\
\hline Electricity (kWh) & 0.042 & $342,937,465$ & $14,403,374$ & 85.19 & $2,801,716$ & 117,672 & 71.92 \\
\hline Steam $(\mathrm{kg})$ & 0.0012 & $1,524,952,912$ & $1,829,943$ & 10.82 & $31,207,365$ & 37,449 & 22.89 \\
\hline Cooling water (kg) & 0.0001 & $5,801,250,036$ & 580,125 & 3.43 & $81,279,300$ & 8,128 & 4.97 \\
\hline Chilled water (kg) & 0.0004 & $233,378,224$ & 93,351 & 0.55 & $1,796,161$ & 718 & 0.44 \\
\hline Total & & & $\$ 16,906,677$ & $100 \%$ & & $\$ 163,615$ & $100 \%$ \\
\hline
\end{tabular}

[a] Unit reference: $\mathrm{kWh}=$ kilowatt hour; $\mathrm{kg}=$ kilogram.

[b] From Aden et al. (2002). 
Table 7. Annual operating costs for both the SmF and SSC enzyme production methods (year 2004 prices). ${ }^{[a]}$

\begin{tabular}{lccccc}
\hline & \multicolumn{2}{c}{ SmF } & & \multicolumn{2}{c}{ SSC } \\
\cline { 2 - 3 } \cline { 5 - 6 } Cost Item & $\$$ & $\%$ & & $\$$ & $\%$ \\
\hline Raw materials & $3,753,000$ & 12.27 & & 458,000 & 5.57 \\
Labor & $2,773,000$ & 9.07 & & $2,116,000$ & 25.71 \\
Facility & $6,727,000$ & 22.00 & & $5,175,000$ & 62.87 \\
Laboratory/QC/QA & 416,000 & 1.36 & & 317,000 & 3.86 \\
Utilities & $16,907,000$ & 55.30 & & 164,000 & 1.99 \\
\hline Total & $\$ 30,576,000$ & $100 \%$ & & $\$ 8,230,000$ & $100 \%$ \\
\hline
\end{tabular}

[a] Software SuperPro Designer 5.5 simulation output.

Table 8. Itemized unit costs for enzyme production (year 2004 prices). [a]

\begin{tabular}{lccccc}
\hline & \multicolumn{2}{c}{$\mathrm{SmF}$} & & \multicolumn{2}{c}{$\mathrm{SSC}$} \\
\cline { 2 - 3 } \cline { 5 - 6 } Cost Item & $\%$ & $\$$ & & $\%$ & $\$$ \\
\hline Raw materials & 12.27 & 4.95 & & 5.57 & 0.87 \\
Labor & 9.07 & 3.66 & & 25.71 & 4.03 \\
Facility & 22.00 & 8.88 & & 62.87 & 9.85 \\
Laboratory/QC/QA & 1.36 & 0.55 & & 3.86 & 0.60 \\
Utilities & 55.30 & 22.32 & & 1.99 & 0.31 \\
\hline Total & 100.00 & $\$ 40.36$ & 100.00 & $\$ 15.67$ \\
\hline
\end{tabular}

[a] Software SuperPro Designer 5.5 simulation output.

Table 9. Sensitivity analyses for the influence of production scale on the unit costs for enzyme production using the SSC method (year 2004 prices). [a]

\begin{tabular}{ccc}
\hline $\begin{array}{c}\text { Production Scale } \\
(\mathrm{kg} / \mathrm{batch} \text { from main fermentor })\end{array}$ & $\begin{array}{c}\text { SmF Unit Cost } \\
(\$ / \mathrm{kg})\end{array}$ & $\begin{array}{c}\text { SSC Unit Cost } \\
(\$ / \mathrm{kg})\end{array}$ \\
\hline$-80 \%(2,000)$ & 58.90 & 42.51 \\
$-60 \%(4,000)$ & 47.30 & 26.46 \\
$-40 \%(6,000)$ & 43.35 & 20.54 \\
$-20 \%(8,000)$ & 41.33 & 17.34 \\
Base $(10,000)$ & 40.36 & 15.67 \\
$+20 \%(12,000)$ & 39.12 & 13.86 \\
$+40 \%(14,000)$ & 38.54 & 12.79 \\
$+60 \%(16,000)$ & 38.10 & 11.95 \\
$+80 \%(18,000)$ & 37.77 & 11.27 \\
\hline
\end{tabular}

[a] Software SuperPro Designer 5.5 simulation output.

costs to produce enzymes by randomly sampling from the input variable distributions and calculating output response based on these input variables (10000 times in this section).

The variables examined in the Monte Carlo analysis included (1) purchase prices for raw materials (paper pulp, cellulose, and media), (2) facility costs, and (3) the cellulose-enzyme conversion ratio. Probability distributions were assigned to each variable (table 10) to quantify the uncertainty of these variables in our Monte Carlo analysis. According to Aden et al. (2002), the price variables for paper pulp and cellulose powder have an exponential distribution. The price variable for the media was assigned a lognormal distribution, with its mean value equaling its initial price and standard deviation equaling one-tenth of this price. All equipment costs were estimated from base equipment costs using equation 2. Since Peters et al. (2003) reported a 30\% to $40 \%$ error associated with this method, we assumed that the equipment cost estimates (tables 2 and 3) were conservative in our base analysis. Therefore exponential distributions were assigned to the facility costs with a mean
Table 10. Input parameter distribution for Monte Carlo analysis.

\begin{tabular}{|c|c|c|c|c|c|c|}
\hline & $\begin{array}{l}\text { Base } \\
\text { Value }\end{array}$ & $\begin{array}{l}\text { Distribution } \\
\text { Function }\end{array}$ & $\begin{array}{c}\text { Most } \\
\text { Likely } \\
\text { Value[a] }\end{array}$ & $\begin{array}{c}\text { Standard } \\
\text { Deviation }\end{array}$ & Min & $\operatorname{Max}$ \\
\hline Paper pulp (\$/kg) & 0.000 & Exponential & 0.001 & 0.001 & 0 & Infinity \\
\hline Cellulose $(\$ / \mathrm{kg})$ & 0.000 & Exponential & 0.01 & 0.01 & 0 & Infinity \\
\hline Media $(\$ / k g)$ & 0.0038 & Lognormal & 0.0038 & 0.0038 & 0 & Infinity \\
\hline Facility rate & 1 & Exponential & 5 & 5 & 0 & Infinity \\
\hline $\begin{array}{l}\text { Cellulose-enzyme } \\
\text { conversion ratio }\end{array}$ & 0.02 & Triangular & 0.02 & N/A & 0.02 & 0.04 \\
\hline
\end{tabular}

[a] Mean value for lognormal distribution.

five times greater than the initial value. The cellulose enzyme conversion ratio was simulated using 0.02 (see eq. 1 and table 1). We allowed the conversion ratio to vary randomly from 0.02 to 0.04 , according to a triangular distribution with the maximum value $(\max )$ being 0.04 , the minimum value (min) being 0.02 and the most likely value being 0.02 .

When compared with the enzyme market price (from $\$ 90 / \mathrm{kg}$ to $\$ 180 / \mathrm{kg}$ ), Monte Carlo analysis results showed that the SmF method was profitable with $85.8 \%$ certainty, which implied the probability to achieve a profit (greater than or equal to the lower bound of market price, $\$ 90 / \mathrm{kg}$ ) was $85.8 \%$ (fig. 5a). The mean unit cost for enzyme production using the SmF method was $\$ 57.2 / \mathrm{kg}$. Similarly, figure $5 \mathrm{~b}$ showed that the SSC method was profitable with $90.2 \%$ certainty when compared with the enzyme market price (from $\$ 90 / \mathrm{kg}$ to $\$ 180 / \mathrm{kg}$ ). The mean unit cost for enzyme production using the SSC method was $\$ 40.8 / \mathrm{kg}$. Since the randomness (of material prices, etc.) between the SmF and SSC methods are essentially the same, using the same set of random realization of the five parameters in table 10 for both methods, we counted the frequencies that the unit costs using SSC method is cheaper the one using $\mathrm{SmF}$ method, equaling 9,959 out of 10,000 simulations. That is, the unit costs using SSC method is cheaper than the one using SmF method with a certainty of 99.6\%. Therefore, Monte Carlo analysis confirmed that there is a high probability that the SSC method will be more economical than the traditional $\mathrm{SmF}$ method.

\section{Conclusions}

Economic analyses of cellulase production costs using solid state cultivation (SSC) were performed and compared to the production costs from the traditional submerged fermentation $(\mathrm{SmF})$ method using numerical simulation. Results indicated that the unit costs for the cellulase production were $\$ 15.67 / \mathrm{kg}$ cellulase and $\$ 40.36 / \mathrm{kg}$ cellulase (in 2004\$) for the SSC and SmF methods, respectively, compared to the 2004 market price for cellulase enzymes of over $\$ 90 / \mathrm{kg}$ cellulase. A sensitivity analysis conducted using Monte Carlo simulation also suggests that the unit cost of production using the SSC method is lower than the unit cost of production using SmF with a certainty of $99.6 \%$ (9,959 out of 10,000 cases). Our results indicate that the SSC method was more economical than the traditional SmF method; therefore changing the enzyme production method to SSC could reduce the cost of ethanol production from cellulose, with the potential to make bio-ethanol a viable supplemental fuel source. 

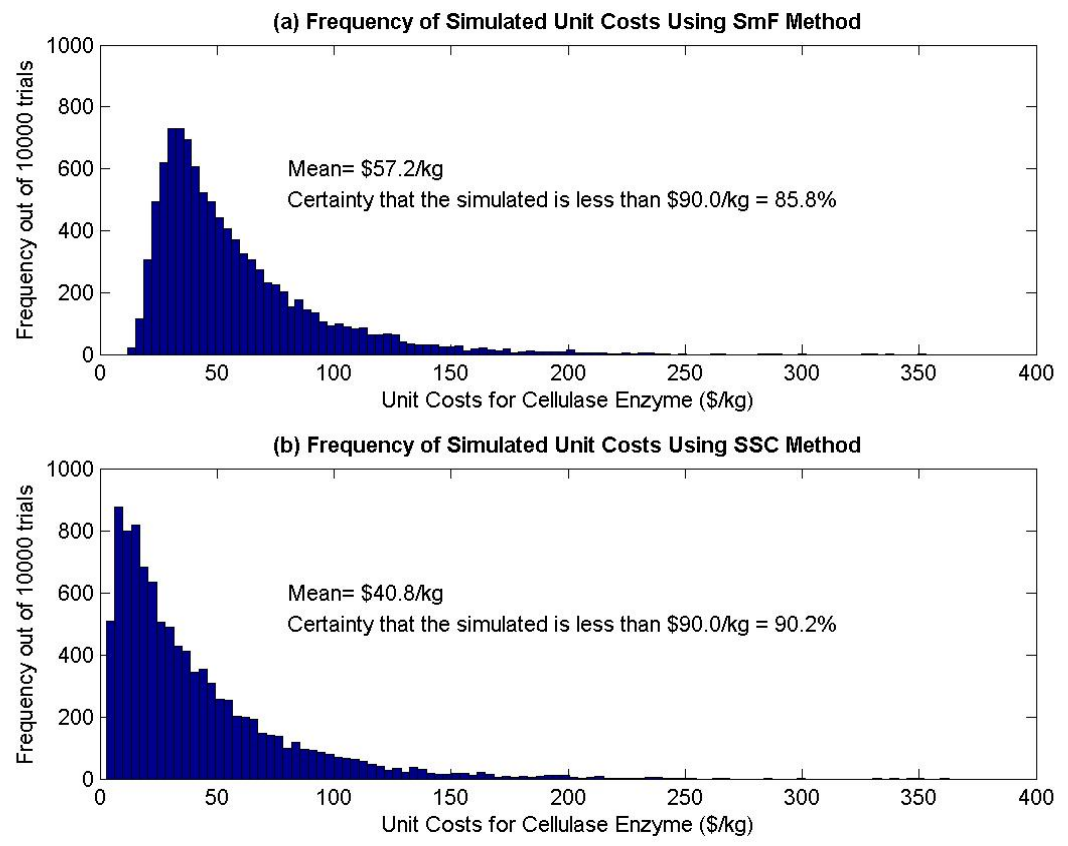

Figure 5. Monte Carlo analysis results: Effect on unit costs for enzyme production.

\section{REFERENCES}

Aden, A., M. Ruth, K. Ibsen, J. Jechura, K. Neeves, J. Sheehan, B. Wallace, L. Montague, A. Slayton, and J. Lukas. 2002. Lignocellulosic biomass to ethanol process design and economics utilizing co-current dilute acid prehydrolysis and enzymatic hydrolysis for corn stover. National Renewable Energy Laboratory (NREL) Report \# TP-510-32438. Golden, Colo.: NREL.

Brown, R. 2003. Biorenewable Resources: Engineering New Products from Agriculture. Boston, Mass.: Blackwell Publishing.

Cannel, E., and M. M. Young. 1980. Solid-state cultivation systems. Process Biochemistry (June/July): 2-7.

Castilho, L. R., C. M. S. Polato, E. A. Baruque, G. L. Sant'Anna, and D. M. G. Freire. 2000. Economic analysis of lipase production by penicillium restrictum in solid-state and submerged fermentations. Biochemical Engineering Journal 4(3): 239-247.

Chinn, M. S., S. E. Nokes, and H. J. Strobel. 2006. Screening of thermophilic anaerobic bacteria for solid substrate cultivation on lignocellulosic substrates. Biotechnology Progress 22(1): 53-59.

Demain, A. L., M. Newcomb, and J. H. D. Wu. 2005. Cellulase, clostridia, and ethanol. Microbiology and Molecular Biology Reviews 69(1): 124-154.

Deschamps, F., and M. C. Huet. 1984. Beta-glucosidase production in agitated solid fermentation, study of its properties. Biotechnology Letters 6(7): 451-456.

Durand, A., S. Almanza, R. Renaud, and J. Maratray. 1997. Solid state fermentations: an attractive alternative to submerged-liquid fermentations. Agro-Food Industry Hi-Tech 8(3): 39-42.

Filer, K. 2006. Personal communication. Research Coordinator for Enzymes. Nicholasville, Ky.: Alltech Biotechnology Inc.

Himmel, M. E., W. S. Adney, J. O. Baker, R. Elander, J. D. McMillan, R. A. Nieves, J. Sheehan, S. R. Thomas, T. B. Vinzant, and M. Zhang. 1997. Advanced bioethanol production technologies: A perspective. In Fuels and Chemicals from Biomass, eds. J. Woodward, B. Saha, 2-45. Washington, D.C.: American Chemical Society.
Holker, U., and J. Lenz. 2005. Solid-state fermentation - Are there any biotechnological advantages? Current Opinion in Microbiology 8(June): 301-306.

Intelligen, Inc. 2006. User's Guide for SuperPro Designer. Scotch Plains, N.J.

Krishna, C. 2005. Solid-state fermentation systems - An overview. Critical Reviews in Biotechnology 25(1/2): 1-30.

Kumar, P. K. R., and B. K. Lonsane. 1987. Potential of fed-batch culture in solid state cultivation for production of gibberellic acid. Biotechnology Letters 9(3): 179-182.

Lynd, L. R., H. E. Grethlein, and R. H. Wolkin. 1989. Fermentation of cellulosic substrates in batch and continuous culture by Clostridium thermocellum. Applied and Environmental Microbiology 55(12): 3131-3139.

Lynd L. R., K. Lyford, C. R. South, P. van Walsum, and K. Levenson. 2001. Evaluation of paper sludge for amenability to enzymatic hydrolysis and conversion to ethanol. Technical Association for the Worldwide Pulp, Paper, and Converting Industry (TAPPI) Journal 84(2): 50-55.

Mitchell, D. A., O. F. Meien, N. Krieger, and F. D. H. Dalsenter. 2003. Recent developments in modeling of solid state fermentation: heat and mass transfer in bioreactors. Biochemical Engineering Journal 13(2): 137-147.

Pandey, A. 2003. Solid-state fermentation. Biochemical Engineering Journal 13(2): 81-84.

Pandey, A., P. Selvakumar, C. R. Soccol, and P. Nigam. 1999. Solid state cultivation for the production of industrial enzymes. Current Science 77(1): 149-162.

Peters, M. S., K. D. Timmerhaus, and R. E. West. 2003. Plant Design and Economics for Chemical Engineers, 5th ed. New York: McGraw-Hill.

Ruth, M. 2003. Technical and economic assessment: Review and proposed directions. National Renewable Energy Laboratory Symposium. Available at http://www.eere.energy.gov/biomass/ pdfs/esp3_mr_process_eng_esp_fy03_review.pdf. Accessed February $\overline{2} 00 \overline{7}$.

Shuler, M. L., and F. Kargi. 1992. Bioprocess Engineering: Basic Concepts. Englewood Cliffs, N.J.: Prentice Hall. 
U.S. Department of Energy, Office of Energy Efficiency and Renewable Energy (US-DOE-EERE). 2007. Mission. Internet site: http://www.eere.energy.gov/office_eere/mission.html (accessed July 2007).

Wooley, R., M. Ruth, J. Sheehan, K. Ibsen, H. Majdeski, and A. Galvez. 1999. Lignocellulosic Biomass to Ethanol Process Design and Economics Utilizing Co-Current Dilute Acid Prehydrolysis and Enzymatic Hydrolysis Current and Futuristic Scenarios. National Renewable Energy Laboratory (NREL) Report \#TP-580-26157.

Zhang, Y., and L. R. Lynd. 2003. Quantification of cell and cellulase mass concentrations during anaerobic cellulose fermentation: development of an enzyme-linked immunosorbent assay-based method with application to Clostridium thermocellum batch cultures. Analytical Chemistry 75(2): 219-227.

\section{APPENDIX: FLOWSHEETS AND EQUIPMENT OVERVIEW}

In order to conduct economic analyses, we must first specify the steps and corresponding equipment used in the enzyme production. The traditional SmF enzyme production method typically requires downstream processes including enzyme concentration and freeze-drying, while the SSC method does not (see also fig. 2). Since flowsheets are able to represent the biochemical engineering processes (Peters et al., 2003), this section provides flowsheets in figures 3 and 4 to describe the overall enzyme production processes, followed by a general description of related equipment, for the SmF and SSC methods, respectively.

In the SmF enzyme production process (see the flowsheet in fig. 3), the initial bacteria $C$. thermocellum is prepared and transferred from a freezer $\left(-80^{\circ} \mathrm{C}\right)$ into a sterilized shake flask (SFR-101) containing media and cellulose. The freezer and sterilizing equipment were assumed economically negligible since their sizes and costs are relatively small compared with other equipment used in the overall enzyme production process.

The cultures are fermented in the shake flask (SFR-101) for the first time, transferred to seed fermentor \#1 (SF-101) and fermented for a second time, supplied with media and cellulose (substrate) prepared by media blender \#1 (MB-101) and the heat sterilizer \#1 (HS-101). Then the cultures are transferred to seed fermentor \#2 (SF-102) and fermented for a third time, supplied with media and cellulose (substrate) prepared by media blender \#2 (MB-102) and heat sterilizer \#2 (HS-102). Finally the cultures are transferred to the main liquid fermentor (LF-101) and fermented for a fourth time, using paper pulp (substrate, containing cellulose) previously stored in a hopper (HP-101). Separate media is charged into the main liquid fermentor.

Nitrogen sweeps are conducted in all vessels, shake flask, fermentors, and media blenders to guarantee an anaerobic environment. All emission gases from the shake flasks and fermentors are emitted into the air through a mixer (MX-101) and an air filter (AF-101) to contain any bacteria. All the other gases are emitted from the media blenders directly into the air, because the media blenders do not contain bacteria.

The product from the liquid fermentor (LF-101) is the cellulase enzyme, together with some residues and water. A concentrator (EV-101) is used to remove water, and a freeze-dryer (FDR-101) is used to further remove water before the contents form the final product, cellulase. The concentration and freeze-drying activities comprise the downstream process for the $\mathrm{SmF}$ method of enzyme production.

For the SSC methods (see flowsheet in fig. 4), this process is largely the same as the $\mathrm{SmF}$ method, with two differences due to the nature of the solid substrate: (1) the paper pulp and media are sterilized in a sterilizing drum (SD-101), agitated and mixed with the culture transferred from seed fermentor \#2 (SF-102) and transferred to the main solid fermentor (SMF-101) using a sterile conveyor (SC-101). The reason that the SSC methods requires a sterilizing drum is that stirring is very difficult in solid fermentors (SSC method), while stirring is routine for liquid fermentors ( $\mathrm{SmF}$ method). (2) The final product, cellulase, produced from the solid SSC fermentor is assumed ready to be used on-site, so there is no requirement for downstream processes (concentration and freeze-drying) as with the SmF method. 